\title{
Development of Bombay Duck Fish Based Protein Enriched Extruded Noodles: A Candidate for Tailored Noodles Quality
}

\author{
S.S. Mahanand ${ }^{1 *}$, K.K. Dash ${ }^{2}$, T. Ghosh ${ }^{2}$, A.K. Senapati ${ }^{3}$ and V.V. Bansode ${ }^{4}$ \\ ${ }^{I}$ Department of Fish Processing Technology \& Engineering, College of Fisheries, \\ CAU, Lembucherra, Tripura (W) 799210, India \\ ${ }^{2}$ Department of Food Engineering and Technology, Tezpur University, 3 \\ Tezpur, Assam, 784028, India \\ ${ }^{3}$ Centre of Excellence on Post-Harvest Technology, Navsari Agricultural University, \\ Navsari, Gujarat, India \\ ${ }^{4}$ ICAR-Central Tuber Crops Research Institute, Regional Centre, \\ Bhubneswar-751019 Odisha, India \\ *Corresponding author
}

\begin{tabular}{|c|}
\hline \\
\hline $\begin{array}{l}\text { Extrusion, Bombay } \\
\text { duck protein, Wheat } \\
\text { flour, Cooking, } \\
\text { Texture, } \\
\text { Morphology }\end{array}$ \\
\hline Article Info \\
\hline $\begin{array}{l}\text { Accepted: } \\
\text { 07 June } 2019 \\
\text { Available Online: } \\
10 \text { July } 2019\end{array}$ \\
\hline
\end{tabular}

A B S T R A C T

The present investigation aims to extrude a value-added noodle product from wheat flour and protein using Single-screw-extruder. The protein used was extracted from a low-cost Bombay Duck (Harpodon nehereus L.) fish following salt extraction process, which in natural condition has some unattractive odor. For the study, five fish protein enriched samples (with a protein concentration of $12.50,13.99,14.44,15.08$, and $15.88 \%$ respectively) with a control sample ( $0 \%$ fish protein) were prepared for finding the optimum quality. The prepared samples were compared with the commercially available samples in most of the qualities studied such as cooking, textural and morphological study. The cooking properties are found to be optimum in terms of cooking time, cooking loss, swelling index, water absorption, and expansion ratio. The textural properties like Hardness, Gumminess, and Chewiness increase with an increase in protein content of the product. Further, the morphological study gives the evidence of formulating better-interacted wheat flour and protein noodles.

\section{Introduction}

From very past years, there is growing the cases of malnutrition and under-nutrition in the various portion of the world (Caulfield $e t$ al., 2004). The root cause belongs to shifting of consumption pattern from a balanced diet to inadequate and faulty diets (Allen, 1993). 
Further, the protein energy malnutrition causes the death of about 10 million children yearly in the 0-6 years' age group, (Lantham, 1984). In this regards, consumers are in a need of healthy and nutritional products with unchangeable quality (Divine and Lepisto, 2005). As it is well known that protein is one of the essential nutrients for a balanced diet, where fish is a rich source of easily digestible protein that also provides polyunsaturated fatty acids, vitamins and minerals for human nutrition (Schrama et al., 2018; Tibaldi et al., 2018; Khalili et al., 2018). Nevertheless, a large proportion of total landed fish remains unused due to inherent problems like extreme perishability, color, flavor, texture, small size, and high fat content (Gill and Gill, 2005; Lin et al., 2014; Venugopal and Shahidi, 1998).

In the fabricated seafood product, the addition of fat, starch, and non-muscle protein will produce various type of effect of fatty acids salts on the gel structure of fish muscles protein. It provides a scope of incorporating proteins from fish products to different food products for tailored quality. However, various process condition such as high temperature, long time processing, use of chemicals can determinate the quality of protein in fish. Extrusion, a high temperature short time process can be used to preserve quality and producing value-added products such as protein enriched noodles (Linko et al., 1981; Bhandari et al., 2001). However, it appears that there is enough scope of work producing extruded products in the fish muscle. An extruder is primarily a high temperature and short time process helps in maintaining product quality in a high range. However, in most of the cases, the flavors of underutilized fishes are not liked by people. Realizing the crucial picture of malnutrition, cost of increasing the price of conventional fish and popularity of noodles like products, development of protein-enriched noodles could provide health benefits.
Extrusion is a widely used technique to prepare extruded noodles from flours (Shiau and Yeh, 2001; Wu et al., 2017). In comparison to other available techniques, extrusion has many advantages such as versatile nature, high productivity, high quality, the possibility of production design, and the absence of effluents during processing etc. Moreover, extrusion helps in improving the functional characteristics of protein source without losing the protein quality provided if right sets of process variables used, unconventional protein sources can be texturized to an acceptable form through extrusion. Interestingly, co-extrusion of carp and rice observed that the extrudate can be stored for six months at room temperature without the development of any off odor (Maga and Reddy, 1985). Yu et al., (1985) studied the production of fish crackers from a mixture of minced fish and ground tapioca flour in a single screw extruder. The effect of temperature and fish to flour ratio were investigated. Linear expansion of the extrudate on frying was found to increase with temperature up to $1000 \mathrm{C}$. further increase in temperature slightly reduced expansion. Increasing fish content had the opposite effect on expansion. The extruded product was organoleptically acceptable and similar to those prepared by traditional methods.

When fish mince is blended with wheat flour, and co-extruded, some promising extruded products with nutritional combination are produced. Per capita, noodle consumption was increasing day by day and is expected to continually increase.

The most widely consumed noodles are cereals, grain-based products, which generally are low in nutrient and high in fat content. Incorporation of protein into these noodle products could increase their nutritional value and for eradicating protein malnutrition. 
Based on the above discussion, the objective of the present investigation is to extract protein from low-cost fish (Bombay duck) and to develop protein enriched extruded noodles. Further, the study aims to study the effectiveness of protein content on the quality of the protein-rich extruded product in terms of texture, microstructure, rehydration and cooking time.

\section{Materials and Methods}

\section{Collection of raw materials}

Bombay duck (Harpodon nehereus), a tropical marine fish was procured in fresh condition for this study. The fish was used as a protein supplementary unit. Further, the required wheat flour for the experiment was purchased from the local market. The used chemicals and reagents were supplied by Himedia and Merck Laboratories (India). All the chemicals were used without any further purification.

\section{Proximate analysis}

The nutrient composition of selected ginger cultivars such as moisture content, and crude protein content was determined according to standard methods (AOAC, 2010).

\section{Protein Isolation from Bombay duck}

The fish was cut into pieces and then the muscle of the fish was separated with the help of a knife. It was washed properly with tap water. Amount of muscles (flesh) obtained was almost half of the whole fish. After washing the muscles was stirred slowly for 30 min with Phosphate Buffer ( $\mathrm{pH}=6.4)$ (Muscle: Phosphate buffer $=1: 4)$. The mixture was blended in the grinder (Summit, Kolkata) for five minutes. Then it was sieved through a clean muslin cloth. The slurry passed through and was collected while the undissolved part remains on the cloth. The slurry was centrifuged at $6000 \mathrm{rpm}$ for five minutes using a tabletop centrifuge (Remi - R27, Kolkata). The fish got deposited as a gel and the supernatant was rejected. The gel contained a lot of chlorides and washed with distilled water. For washing the gel was stirred in the distilled water and centrifuged similarly as mentioned above. Each time the supernatant was checked with $\mathrm{AgNO}_{3}$ solution for any white ppt. All the operation was done at a low temperature. The chloride-free protein gel was then used in noodle preparation.

\section{Preparation of Protein Enriched Extruded Noodle}

The extracted fish protein was mixed in a grinder with distilled water in a proportion to get a protein solution. After that $500 \mathrm{gms}$ of wheat flour was mixed with protein solution (i.e. $32 \%$ moisture in w.b.) in hand. The blend was then kept in a sealed polythene bag for $1 \mathrm{hr}$ for equilibration. The equilibrated blend was extruded in a prefabricated single screw extruder. During extrusion outside temperature of the barrel was adjusted to $120^{\circ}$ $\mathrm{C}$ which accounted for the inside temperature of $65^{\circ} \mathrm{C}$. The equilibrated blend was fed from the hopper and the product was collected in the form of the rod using a round whole die of diameter $3 \mathrm{~mm}$. The collected product was then dried in room air by spreading on trays. Five samples with different amount of isolated protein gel were prepared along with a control sample. The control sample contained no fish protein.

The extruder used in the present study is a laboratory model single-screw variable length cooking extruder previously developed for extrusion cooking of aqua feeds and snack food for research and development purpose (Giri and Bandyopadhyay, 2000).

\section{Cooking Quality}

The optimum cooking time for each sample was determined by boiling with tap water. The 
ratio of noodle to water used for the cooking test was 1:100 as used by Das (1987). Noodles were added to rapidly boiling water. After each minute of cooking, noodles were removed and squeezed between two transparent glass plates. Noodles were cooked until the white core disappeared. The time required for this process is the cooking time. The water absorption capacity of noodles was determined by measuring the before and after cooked weight, where cooked weight was taken after cooking the cooked noodles and was further drained for $5 \mathrm{~min}$ at room temperature. Cooking loss was determined by evaporation to dryness of the cooking water after separating the cooked noodles. Swelling index was measured from the ratio of water displacement of cooked noodles divided by water displacement of an equivalent amount of uncooked noodles. Expansion ratio for the cooked samples was calculated by measuring the length and diameter of the samples before and after cooking.

\section{Texture analysis in dry condition}

The texture analysis in terms of breaking force of dried noodles of the samples was measured by using Instron universal testing machine (Model-1011). A crosshead speed of $60 \mathrm{~mm} /$ min was used. Load range was $50 \mathrm{~N}$ and chart speed was adjusted to $120 \mathrm{~mm} / \mathrm{min}$. the values of peak stress were recorded in numerical as well as in graphical form. The texture parameters of the cooked samples were measured with a texture analyzer (Texture technologies corp., UK, Model TA XT2, version 05.16 equipped with $25-\mathrm{kg}$ load cell).

\section{Morphological analysis}

The morphological analysis of the extruded samples was done using a Scanning Electron Micrograph (Jeol Jsm-5800 scanning microscope). For the analysis, the samples were cut into thin slices and were attached to stubs using double-sided carbon tapes. Further, the stubs were gold coated using Denton Vae-Sputter Coater to make it conductive and taken for morphological studies.

\section{Results and Discussion}

The color of dry samples prepared in the laboratory was comparable with commercially available noodles. However, there was some fissure seen on the surface of the noodles prepared in the laboratory. No undesirable smell of fish was detected in the noodles enriched with fish protein. The prepared dried samples are shown in the Figure 1. The extrusion was done at taking five various ratios of proteins along with a control sample ( $0 \%$ fish protein) and analyzed for various optimum qualities. The symbol $\mathrm{C}$ is designated for the control sample, whereas Sample 1, Sample 2, Sample 3, Sample 4 and Sample 5 are designated in terms of their fish gel content for 50, 75, 100, 125, and $150 \mathrm{gm}$, respectively. The ratio of wheat flour and fish gel for Sample 1, Sample 2, Sample 3, Sample 4 and Sample 5 was 10:1,10:1.5, 10:2, 10:2.5 and 10:0 respectively. Therefore, the Sample 1, Sample 2, Sample 3, Sample 4 and Sample 5 were names as 10W1FG, 10W1.5FG. 10W2FG, 10W2.5FG and 10W3FG respectively.

With the increase in addition of fish gel from $0-150 \mathrm{gm}$ to the wheat flour $(500 \mathrm{gm})$, there was an increase in the percentage of protein content. The protein percentages of the product samples are given in Table 1, where 10W1FG, 10W1.5FG, 10W2FG, 10W2.5FG and 10W3FG contain protein of 12.50, 13.99, $14.44,15.08$, and $15.88 \%$, respectively. The increase in protein percentage is due to the increase in fish gel percentage in wheat flour. The different protein percentage influenced the noodles quality for their texture and cooking. Further, proteins help in improving 
interaction with starch resulting in a better texture. The moisture content of the samples in the wet basis is shown in Table 1. The moisture content of the samples varied between 4 and $11 \%$ on a dry basis. The moisture content plays a severe in the preservation of noodles as less moisture content helps in long shelf life noodles.

\section{Cooking quality}

The samples were analyzed for their cooking properties such as optimum cooking time, water absorption, swelling index, and cooking loss. The expansion ratio was computed by measuring the length and diameter of the samples before and after cooking. It was found from the Table 2 that expansion ratio of the laboratory made sample varied from 1.12 to 1.15 , and 1.06 to 1.35 considering length and diameter, respectively and for commercial samples, it varied from 1.09 to 1.12 for lengthwise and 1.33 to 1.52 for diameter wise. It is evident from these results that along the diameter swelling of the sample is much more than in lengthwise direction. The result was well in agreement with the commercial noodle.

The optimum cooking time for the dry noodles in tap water has been determined by visual disappearance of white core. It was found out to be $21,13.5,16.5,16,15.5$ and $14 \mathrm{~min}$ for control, 10W1FG, 10W1.5FG, 10W2FG, $10 \mathrm{~W} 2.5 \mathrm{FG}$ and $10 \mathrm{~W} 3 \mathrm{FG}$ respectively as given in Table 2. The mean cooking time of this laboratory prepared samples were much higher than the commercial samples which ranged from 4 to $4.5 \mathrm{~min}$. These higher cooking time of the sample prepared in the laboratory was probably due to the higher diameter of the samples as compared to the commercial samples. It was found that with the increase in protein content, the cooking time decreased. This may be due to the incorporation of fibrous fish muscle, thereby distributing the starch matrix and reducing the compactness of the products which subsequently helps the quick penetration of moisture. The water absorption of the laboratory-prepared samples was varied between 47 to $120 \%$ and the commercial sample (Licia, and plain) were varied between 146 to $156 \%$ as given in Table 2. The higher values of commercial samples may be due to the addition of some other ingredients which were not added in the laboratory-prepared samples. There was no direct relationship found between the swelling Index of the samples and protein content. Table 2 shows that the swelling Index of commercial samples was comparable with the control sample, samples 10W1FG, 10W1.5FG, and 10W3FG; however, for sample 10W2FG, 10W2.5FG exhibited lower swelling index. Sample without fish protein (control sample) indicates about $11.9 \%$ loss on cooking whereas for other samples it ranges between 3 to $11 \%$ as given in Table 2. Presence of protein reduced the cooking loss compared to the non-protein ones.

\section{Texture analysis of dry and wet samples}

The force required to break the samples was almost the same for control, 10W1.5FG and $10 \mathrm{~W} 2.5 \mathrm{FG}$ i.e. the mean range was between 32 to 33 N. Similarly, for sample 10W1FG and $10 \mathrm{~W} 2 \mathrm{FG}$ the mean forces required to break were $14.9 \mathrm{~N}$ and $19.5 \mathrm{~N}$, respectively (Table 3). The results suggested that the texture may be affected by dimension, protein content of the materials, the noodles varied in their diameters resulting variation in texture properties. Under wet conditions of the samples, it was found that a few textural properties showed a significant change with an increase in protein content of the product. It was also found that the textural properties like Hardness, Gumminess, and Chewiness increase with an increase in protein content of the product. 
Table.1 Protein percentages of the laboratory prepared product

\begin{tabular}{|l|c|c|c|c|}
\hline \multicolumn{1}{|c|}{ Sl. No. } & Fish gel $(\mathbf{g})$ & Wheat flour $\mathbf{( g )}$ & Protein $(\mathbf{\%})$ & Moisture content (\%) \\
\hline Control & 0 & 500 & 11.43 & $\mathbf{8 . 6 3}$ \\
\hline $\mathbf{1 0 W 1 F G}$ & 50 & 500 & 12.50 & $\mathbf{9 . 0 4}$ \\
\hline $\mathbf{1 0 W 1 . 5 F G}$ & 75 & 500 & 13.99 & $\mathbf{7 . 7 3}$ \\
\hline $\mathbf{1 0 W 2 F G}$ & 100 & 500 & 14.44 & $\mathbf{4 . 7 7}$ \\
\hline $\mathbf{1 0 W 2 . 5 F G}$ & 125 & 500 & 15.08 & $\mathbf{8 . 9 1}$ \\
\hline $\mathbf{1 0 W 3 F G}$ & $\mathbf{1 5 0}$ & $\mathbf{5 0 0}$ & $\mathbf{1 5 . 8 0}$ & $\mathbf{1 0 . 4 9}$ \\
\hline
\end{tabular}

Table. 2 Cooking properties of extruded samples

\begin{tabular}{|c|c|c|c|c|c|c|c|}
\hline SI. No. & $\begin{array}{c}\text { Protein } \\
(\boldsymbol{\%})\end{array}$ & $\begin{array}{c}\text { Expansion } \\
\text { ratio } \\
\text { (length) }\end{array}$ & $\begin{array}{c}\text { Expansion } \\
\text { ratio } \\
(\mathbf{d i a m e t e r )}\end{array}$ & $\begin{array}{c}\text { Cooking } \\
\text { time } \\
(\mathbf{m i n})\end{array}$ & $\begin{array}{c}\text { Water } \\
\text { absorption } \\
(\boldsymbol{\%})\end{array}$ & $\begin{array}{c}\text { Swelling } \\
\text { Index }\end{array}$ & $\begin{array}{c}\text { Cooking } \\
\text { loss } \\
(\boldsymbol{\%})\end{array}$ \\
\hline Control & 11.43 & 1.15 & 1.06 & 21 & 60 & 3 & 11.9 \\
\hline 10W1FG & 12.50 & 1.15 & 1.35 & 13.5 & 120 & 4 & 5.2 \\
\hline 10W1.5FG & 13.99 & 1.12 & 1.18 & 16.5 & 64 & 2 & 4.4 \\
\hline 10W2FG & 14.44 & 1.12 & 1.24 & 16 & 102 & 1.75 & 3.3 \\
\hline 10W2.5FG & 15.08 & 1.12 & 1.15 & 15.5 & 47 & 1.75 & 10.6 \\
\hline 10W3FG & 15.80 & 1.12 & 1.27 & 14 & 96 & 3 & 6.3 \\
\hline Licia & - & 1.12 & 1.52 & 4 & 146 & 3.75 & 23.1 \\
\hline Plain & - & 1.09 & 1.33 & 4.5 & 156 & 3.75 & 9.6 \\
\hline
\end{tabular}

Table.3 Texture properties of extruded noodles

\begin{tabular}{|l|c|c|}
\hline \multicolumn{1}{|c|}{ Sample name } & Protein $\mathbf{( \% )}$ & Breaking force $\mathbf{( N )}$ \\
\hline Control & 11.43 & 32.6 \\
\hline 10W1FG & 12.50 & 14.9 \\
\hline 10W1.5FG & 13.99 & 32.4 \\
\hline 10W2FG & 14.44 & 19.5 \\
\hline 10W2.5FG & 15.08 & 33.1 \\
\hline 10W3FG & 15.80 & 10.4 \\
\hline
\end{tabular}

Fig.1 Extruded protein rich wheat flour based noodles

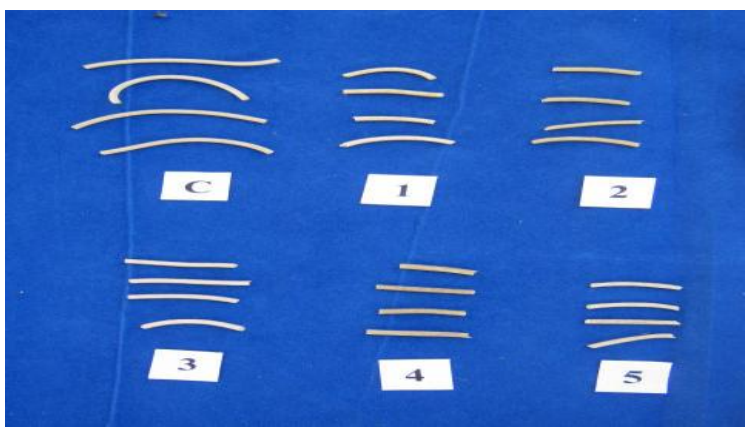


Fig.2 A. Control Sample

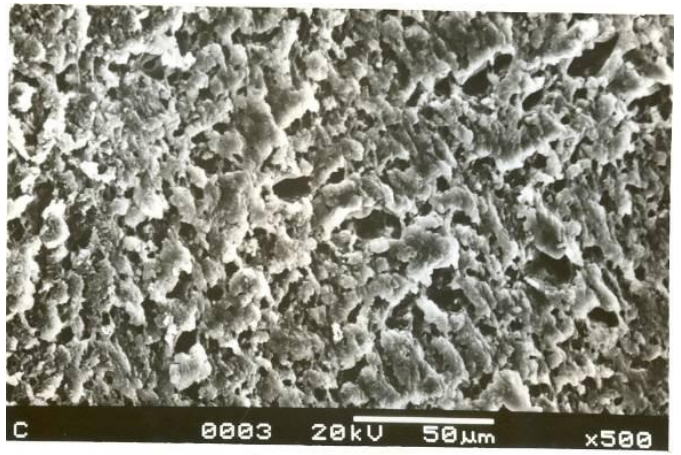

\section{Cooking quality}

The samples were analyzed for their cooking properties such as optimum cooking time, water absorption, swelling index, and cooking loss. The expansion ratio was computed by measuring the length and diameter of the samples before and after cooking. It was found from the Table 2 that expansion ratio of the laboratory made sample varied from 1.12 to 1.15 , and 1.06 to 1.35 considering length and diameter, respectively and for commercial samples, it varied from 1.09 to 1.12 for lengthwise and 1.33 to 1.52 for diameter wise. It is evident from these results that along the diameter swelling of the sample is much more than in lengthwise direction. The result was well in agreement with the commercial noodle. The optimum cooking time for the dry noodles in tap water has been determined by visual disappearance of white core. It was found out to be $21,13.5,16.5,16$, 15.5 and $14 \mathrm{~min}$ for control, 10W1FG, 10W1.5FG, 10W2FG, 10W2.5FG and 10W3FG respectively as given in Table 2 . The mean cooking time of this laboratory prepared samples were much higher than the commercial samples which ranged from 4 to $4.5 \mathrm{~min}$. These higher cooking time of the sample prepared in the laboratory was probably due to the higher diameter of the samples as compared to the commercial samples. It was found that with the increase in protein content, the cooking time decreased.

\section{B. Sample 5 (10W3FG)}

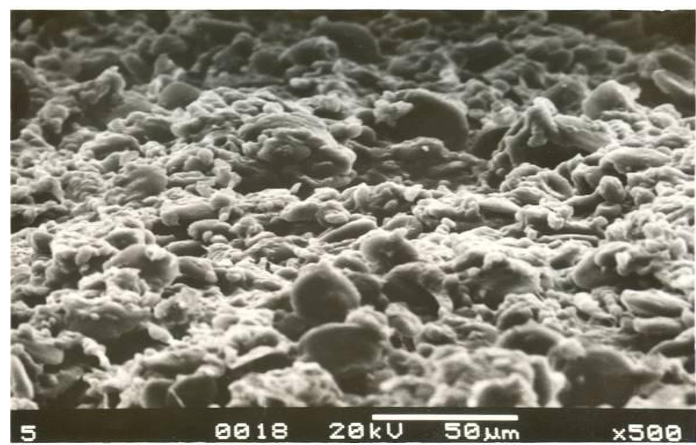

This may be due to the incorporation of fibrous fish muscle, thereby distributing the starch matrix and reducing the compactness of the products which subsequently helps the quick penetration of moisture.

The water absorption of the laboratoryprepared samples was varied between 47 to $120 \%$ and the commercial sample (Licia, and plain) were varied between 146 to $156 \%$ as given in Table 2 . The higher values of commercial samples may be due to the addition of some other ingredients which were not added in the laboratory-prepared samples. There was no direct relationship found between the swelling Index of the samples and protein content. Table 2 shows that the swelling Index of commercial samples was comparable with the control sample, samples 10W1FG, 10W1.5FG, and 10W3FG; however, for sample 10W2FG, 10W2.5FG exhibited lower swelling index. Sample without fish protein (control sample) indicates about $11.9 \%$ loss on cooking whereas for other samples it ranges between 3 to $11 \%$ as given in Table 2. Presence of protein reduced the cooking loss compared to the non-protein ones.

\section{Texture analysis of dry and wet samples}

The force required to break the samples was almost the same for control, 10W1.5FG and $10 \mathrm{~W} 2.5 \mathrm{FG}$ i.e. the mean range was between 
32 to 33 N. Similarly, for sample 10W1FG and $10 \mathrm{~W} 2 \mathrm{FG}$ the mean forces required to break were $14.9 \mathrm{~N}$ and $19.5 \mathrm{~N}$, respectively (Table 3). The results suggested that the texture may be affected by dimension, protein content of the materials, the noodles varied in their diameters resulting variation in texture properties. Under wet conditions of the samples, it was found that a few textural properties showed a significant change with an increase in protein content of the product. It was also found that the textural properties like Hardness, Gumminess, and Chewiness increase with an increase in protein content of the product.

\section{Morphological analysis}

The Surface morphological analyses of prepared extruded noodles are shown in Figure 2. The control sample had uniform string like structure throughout the surface. However, the surface micrograph of protein containing samples 10W3FG (Fig 3B) provide presence of particles within string like structures. Further, the surface micrograph of protein incorporated noodles shows the interaction of starch and protein fraction. The surface micrograph of sample 10W3FG contain highest protein content showing more uniformity for presence of particles in the continuous string like surface of starch. Moreover, at high protein content the presence of intact starch granules was also indicated.

In conclusion, the present investigation demonstrates the extrusion of Bombay duck protein dispersed wheat flour noodles. The effect of protein on the quality of noodles in comparison to available commercial products has been studied. Moreover, cooking properties of the noodles was thoroughly described to check the effect of protein on noodles. The texture properties for dried and wet noodles has been studied thoroughly to find the protein effectiveness on textural properties such as hardness, cohesiveness, springiness, resilience, gumminess, chewiness and adhesiveness. The textural properties are comparable with the commercially available samples. Further, morphological analysis provides the evident of interacting phases of starch and protein molecules. In this regards, the present study provides a value added food product for balanced diet.

\section{References}

Allen, L. H., 1993. The nutrition CRSP: what is marginal malnutrition, and does it affect human function. Nutrition Reviews. 51: 255-267.

AOAC, 2010. Official Methods of Analysis. $18^{\text {th }}$ Edition, Revision 3, Association of Official Analytical Chemists. Washington DC.

Bhandari, B., D'arcy, B., and Young, G., 2001. Flavour retention during high temperature short time extrusion cooking process: a review. International Journal of Food Science and Technology. 36: 453-461.

Caulfield, L. E., de Onis, M., Blössner, M., and Black, R. E., 2004. Under nutrition as an underlying cause of child deaths associated with diarrhea, pneumonia, malaria, and measles. The American Journal of Clinical Nutrition. 80: 193198.

Das, M., 1987. Studies on Physico Chemical aspects of myosin and preparation of myosin enriched foods. Ph.D. Thesis, Jadavpur University, Kolkata.

Divine, R. L., and Lepisto, L., 2005. Analysis of the healthy lifestyle consumer. Journal of Consumer marketing. 22: 275-283.

Gill, A. O., and Gill, C. O., 2005. Preservative packaging for fresh meats, poultry, and fin fish. In Innovations in food packaging. 204-226. 
Giri, S. K., and Bandyopadhyay, S., 2000. Effect of extrusion variables on extrudate characteristics of fish musclerice flour blend in single screw extruder. J. Food Process. Pres. 24: 177190.

Khalili Tilami, S., and Sampels, S., 2018. Nutritional value of fish: lipids, proteins, vitamins, and minerals. Reviews in Fisheries Science and Aquaculture. 26: 243-253.

Lantham, M.C., 1984. Strategies for control of malnutrition and influence of nutritional sciences. FAO World review of food policy and nutrition. Food and Nutri. 10: 5 .

Lin, H. M., Deng, S. G., and Huang, S. B., 2014. Antioxidant Activities of Ferrous Chelating Peptides Isolated From Five Types of Low Value Fish Protein Hydrolysates. Journal of Food Biochemistry. 38:627-633.

Linko, P., Colonna, P., and Mercier, C., 1981. High-temperature, short-time extrusion cooking [Cereal products]. Advances in Cereal Science and Technology.

Maga, J. A., and Reddy, T., 1985. Coextrusion of carp (Cyprinus carpio) and rice flour. J. Food Proc. Pres. 9: 121128.

Schrama, J. W., Haidar, M. N., Geurden, I., Heinsbroek, L. T., and Kaushik, S. J., 2018. Energy efficiency of digestible protein, fat and carbohydrate utilisation for growth in rainbow trout and Nile tilapia. British Journal of Nutrition. 119: 782-791.

Shiau, S. Y., and Yeh, A. I., 2001. Effects of alkali and acid on dough rheological properties and characteristics of extruded noodles. Journal of Cereal Science. 33: 27-37.

Tibaldi, E., Zittelli, G. C., Parisi, G., Bruno, M., Giorgi, G., Tulli, F., and Poli, B. M., 2015. Growth performance and quality traits of European sea bass (D. labrax) fed diets including increasing levels of freeze-dried Isochrysis sp. (TISO) biomass as a source of protein and n-3 long chain PUFA in partial substitution of fish derivatives. Aquaculture. 440: 60-68.

Venugopal, V., and Shahidi, F., 1998. Traditional methods to process underutilized fish species for human consumption. Food Reviews International. 14: 35-97.

Wu, N. N., Tan, B., Li, S. S., Tian, X. H., Liu, M., Liu, Y. X., and Zhai, X. T., 2017. Cooking Quality, Antioxidant Properties, and Starch Digestibility of Wheat Noodles Substituted with Extruded Brown Rice Flour. Cereal Chemistry. 94: 464-470.

Yu, S.Y., Mitchell, J.R., and Abdullah, A., 1981. Production in acceptability testing of fish crackers (Keropok) prepared by extrusion method. Food Technol. 16: $51-58$.

\section{How to cite this article:}

Mahanand, S.S., K.K. Dash, T. Ghosh, A.K. Senapati and Bansode, V.V. 2019. Development of Bombay Duck Fish Based Protein Enriched Extruded Noodles: A Candidate for Tailored Noodles Quality. Int.J.Curr.Microbiol.App.Sci. 8(07): 447-455. doi: https://doi.org/10.20546/ijcmas.2019.807.055 